\begin{tabular}{|c|c|}
\hline JACE (Journal of Agribusiness and Community Empowerment) & Info: \\
\hline Published by PoliteknikPertanian Negeri Payakumbuh & Received 0601202 \\
\hline http://jurnalpolitanipyk.ac.id/index.php/JACE & Revised 1409202 \\
\hline ISSN 2655-4526 (online) 2655-2965 (print) & Published 250920 \\
\hline
\end{tabular}

\title{
Analysis of Mangosteen Marketing in Pulau Rambai Village Kampa District Kampar Regency
}

\author{
Putri Sari, Eliza, Novia Dewi \\ Jurusan Agribisnis, Fakultas Pertanian, Universitas Riau, email: putrisari2807@gmail.com, eliza_unri@yahoo.com, \\ dewinovia642@gmail.com \\ Corresponding author : Putri Sari \\ email: putrisari2807@gmail.com
}

\begin{abstract}
Abstrak
Harga manggis ditentukan oleh pedagang yang cenderung berfluktuasi menyebabkan posisi tawar menawar petani lemah. Harga yang ditentukan sepihak oleh para pedagang, membuat petani hanya sebagai penerima harga (price taker). Analisis efisiensi pemasaran manggis perlu dilakukan sehingga dapat diketahui penyebab rendahnya daya tawar petani dan fluktuasi harga serta tingkat efisiensi pada setiap saluran pemasaran. Penelitian bertujuan menganalisis fungsi-fungsi pemasaran, biaya dan efisiensi pemasaran buah manggis di Desa Pulau Rambai Kecamatan Kampa Kabupaten Kampar.Metode yang digunakan adalah metode survei. Pengambilan sampel petani pada penelitian ini digunakan cara simple random sampling dan sampel pedagang diambil secara sensus. Analisis data secara deskriptif dan kuantitatif. Hasil penelitian diperoleh bahwa fungsi-fungsi pemasaran dilakukan oleh setiap lembaga pemasaran yaitu fungsi pertukaran, fungsi fisik dan fungsi fasilitas. Fungsi pertukaran yang dilakukan berupa fungsi penjualan dan pembelian. Fungsi fisik yang dilakukan berupa fungsi pengemasan, pengangkutan dan penyimpanan. Fungsi fasilitas yang dilaksanakan berupa fungsi sortasi dan grading, pembiayaan, penanggungan risiko dan informasi pasar. Terdapat dua saluran pemasaran manggis di Desa Pulau Rambai. Analisis efisiensi saluran pemasaran yang paling efisien dilihat dari perhitungan biaya pemasaran dan efisiensi pemasaran adalah di saluran pemasaran dua.
\end{abstract}

Kata Kunci: manggis, fungsi pemasaran, efisiensi pemasaran

\begin{abstract}
Mangosteen prices are determined by traders who tend to speculate, causing a weak bargaining position for farmers. Prices are determined unilaterally by traders, making farmers position only as price takers. Mangosteen marketing efficiency analysis needs to be done so that it can discover the cause of the low bargaining power of farmers and price fluctuations and the level of efficiency in each marketing channel. The study aims to analyze the marketing functions, costs, and the marketing efficiency of mangosteen fruit in Pulau Rambai Village, Kampa District, Kampar Regency. The method used is a survey method. Farmer sampling in this study used a simple random sampling method, and as for the traders, samples were taken by census method. The data analysis used is descriptive and quantitative. The results of the study highlight that the marketing functions carried out by each marketing institution are the exchange function, physical function, and facility functions. The exchange function is carried out in the form of a sale and purchase function. Physical functions is performed in the form of packaging, transportation and storage functions. The function of the facilities carried out in the forms of the activities of sorting and grading, financing, risk management, and market information. There are two mangosteen marketing channels in Desa Rambai Island. The most efficient marketing channels are determinedby thecalculation of marketing costs and marketing efficiency. The most efficient chaanel in this study is marketing channel number two.
\end{abstract}

Keywords: mangosteen, marketing function, marketing efficiency 


\section{Pendahuluan}

Indonesia merupakan negara dengan sumberdaya hortikultura yang melimpah yang bisa diandalkan sebagai kekuatan daya saing nasional secara global. Komoditas hortikultura merupakan komoditas potensial yang mempunyai nilai ekonomi tinggi dan memiliki potensi untuk terus dikembangkan.Salah satu komoditas hortikultura yang prospektif untuk dikembangkan di Indonesia adalah manggis[1]. Manggis (Garcinia mangostana L.) merupakan buah khas daerah tropis dan termasuk komoditas ekspor unggulan [2]. Pemerintah telah menetapkan manggis sebagai komoditas unggulan nasional dalam RUSNAS Buah (Riset Unggulan Strategis Nasional Buah) sejak tahun 2000. Hal tersebut dikarenakan manggis memiliki potensi untuk terus dikembangkan. Pemerintah berusaha untuk memperbaiki teknologi produksi di tingkat petani dan menemukan varietas unggul dengan produktivitas yang optimal [3]. Permintaan terhadap manggis dari dalam negeri maupun luar negeri mengalami peningkatan selama beberapa tahun terakhir. Ekspor buah manggis Indonesia pada tahun 2016 sebesar 34,95 ribu ton dengan volume produksi sebesar 162.862 ton menjadi penyumbang devisa terbesar dari buah-buahan tahunan dengan nilai US\$ 20.220.359. Sebagian besar buah manggis diekspor ke Vietnam, Malaysia, dan Hongkong. Dibandingkan dengan tahun 2015, volume ekspor manggis meningkat dengan nilai ekspor US\$17.212.084 [4].

Salah satu kabupaten yang berada di wilayah Provinsi Riau yang terkenal dengan hasil buahbuahannya adalah Kabupaten Kampar. Berdasarkan data Badan Pusat Statistik Provinsi Riau tahun 2017, produksi manggis di Kabupaten Kampar pada tahun 2017 sebesar 2.971,5 ton yang merupakan penghasil manggis terbesar di antara kabupaten yang ada di Provinsi Riau. Desa Pulau Rambai merupakan salah satu daerah penghasil manggis di Kecamatan Kampa Kabupaten Kampar. Berdasarkan hasil wawancara dengan Bapak Azwir sebagai ketua kelompok tani Pulau Rambai I usahatani komoditi manggis di Desa Pulau Rambai tergolong baru, karena komoditi manggis mulai ditanam pada tahun 2004 dan mulai berproduksi pada tahun 2015. Sistem pemasaran yang ada di Desa Pulau Rambai pada umumnya melalui lembaga pemasaran. Lembaga pemasaran yang berperan di Desa Pulau Rambai adalah pedagang pengumpul dan pedagang besar. Lembaga pemasaran tersebut berperan sebagai penghubung mekanisme pasar dan membentuk pola jalur distribusi manggis atau saluran pemasaran manggis dari produsen (petani) sampai ke konsumen akhir. Pada komoditas manggis saat ini banyak dihadapkan pada permasalahan pemasaran yang umumnya terdapat pada penanganan pascapanen yang belum sepenuhnya dilaksanakan secara baik dan benar oleh produsen (petani) maupun lembaga pemasaran. Kondisi tersebut menyebabkan kualitas buah yang dihasilkan menjadi menurun, sehingga harga jual yang diperoleh menjadi rendah.

Hasil produksi manggis dipasarkan melalui dua konsumen akhir yaitu eksportir untuk manggis kualitas layak ekspor atau super (SP) dan pedagang lokal untuk manggis kualitas bekas sortir (BS). Adapun saluran pemasaran yang pertama yaitu petani memasarkan manggis melalui pedagang pengumpul selanjutnya ke pedagang besar kemudian pedagang besar menjual manggis kepada eksportir dan pedagang lokal. Rata-rata harga jual manggis melalui pedagang pengumpul sebesar Rp $11.500,00$ per kilonya. Pada pola pemasaran yang kedua yaitu dari petani manggis langsung dijual ke pedagang besar selanjutnya kepada eksportir dan pedagang lokal. Rata-rata harga jual yang didapatkan petani sebesar Rp 12.057,82 per kilo. Dibandingkan dengan pola pemasaran yang pertama harga jual manggis yang didapatkan petani lebih rendah dibandingkan dengan pola pemasaran kedua.

Adanya perbedaan saluran pemasaran akan mengakibatkan perbedaan pada fungsi-fungsi pemasaran yang dilakukan oleh setiap lembaga pemasaran yang terlibat. Perbedaan saluran pemasaran yang terjadi di Desa Pulau Rambai juga dapat mengakibatkan adanya perbedaan dari sistem pembelian dan penjualan. Saluran pemasaran yang dipilih oleh petani, fungsi pemasaran yang dilakukan dan biaya pemasaran yang dikeluarkan oleh masing-masing lembaga pemasaran yang terlibat akan mengakibatkan perbedaan harga yang diterima oleh petani dan harga yang dibayarkan oleh konsumen. Analisis pemasaran manggis perlu dilakukan sehingga dapat diketahui saluran pemasaran mana yang lebih efisien. Saluran pemasaran dapat menggambarkan rentang harga yang terbentuk serta hubungan antara biaya pemasaran dan keuntungan yang diperoleh dari masing-masing lembaga pemasaran. Berdasarkan uraian tersebut maka tujuan dalam penelitian ini adalah (1) Menganalisis fungsi-fungsi pemasaran buah manggis di Desa Pulau Rambai Kecamatan Kampa Kabupaten Kampar; (2) Menganalisis biaya dan efisiensi pemasaran buah manggis di Desa Pulau Rambai Kecamatan Kampa Kabupaten Kampar. 


\section{Metode Penelitian}

Penelitian ini dilaksanakan di Desa Pulau Rambai Kecamatan Kampa Kabupaten Kampar, Provinsi Riau. Penentuan lokasi penelitian dilakukan secara sengaja (purposive) dengan pertimbangan bahwa usahatani komoditi manggis di Desa Pulau Rambai tergolong baru dan sudah mulai berproduksi pada tahun 2015. Metode penelitian yang digunakan adalah metode survei. Pengambilan sampel dilakukan dengan cara simple random sampling dari jumlah petani yang tergabung dalam kelompok tani Pulau Rambai I sebanyak 89 petani. Jumlah responden petani yang digunakan adalah 30 orang yang dianggap telah mewakili populasi petani manggis di Desa Pulau Rambai. Penentuan jumlah sampel petani responden menggunakan rumus Slovin. Rumus slovin adalah rumus yang digunakan untuk menghitung ukuran sampel minimal suatu penelitian yang mengestimasi proporsi. Sedangkan jumlah sampel pedagang diambil secara sensus. Jenis data dalam penelitian ini adalah data primer dan sekunder. Analisis data untuk tujuan pertama yaitu fungsi-fungsi pemasaran dianalisis secara deskriptif.Tujuan penelitian kedua, menganalisis biaya dan efisiensi pemasaran menggunakan metode kuantitatif

\section{Analisis Fungsi pemasaran}

Analisis fungsi pemasaran digunakan untuk mengetahui kegiatan pemasaran manggis yang dilakukan lembaga pemasaran di Desa Pulau Rambai dalam menyalurkan buah manggis dari petani hingga ke konsumen. Analisis fungsi pemasaran manggis dapat dilihat dari fungsi pertukaran yang terdiri dari fungsi pembelian dan penjualan, fungsi fisik yang terdiri dari fungsi pengangkutan, penyimpanan, dan pengolahan, serta fungsi fasilitas yang terdiri dari standarisasi dan grading, penanggungan risiko, pembiayaan dan informasi pasar.

Analisis Biaya dan Efisiensi Pemasaran

1. Analisis Biaya Pemasaran

Analisis biaya pemasaran dilakukan dengan mengidentifikasi komponen-komponen biaya yang dikeluarkan oleh para lembaga pemasaran. Biaya pemasaran adalah biaya yang dikeluarkan untuk memasarkan suatu komoditi dari produsen ke konsumen yang dirumuskan sebagai berikut [5].

Dimana :

$$
\mathrm{Bp}=\mathrm{Bp} 1+\mathrm{Bp} 2+\ldots . . . \mathrm{Bpn}
$$

$\mathrm{Bp}=$ Biaya pemasaran manggis $(\mathrm{Rp} / \mathrm{kg})$

$\mathrm{Bp} 1, \mathrm{Bp} 2 \ldots \mathrm{Bpn}=$ Biaya pemasaran tiap-tiap lembaga pemasaran manggis $(\mathrm{Rp} / \mathrm{kg})$

\section{Analisis Efisiensi Pemasaran}

Analisis Efisiensi Pemasaran merupakan suatu sistem pemasaran yang efisien dengan menyampaikan hasil dari petani ke konsumen dengan biaya seminimal mungkin dan melakukan pembagian yang adil dari keseluruhan harga yang dibayar konsumen akhir terhadap pihak yang terlibat dalam pemasaran tersebut [6]. Efisiensi pemasaran adalah perbandingan antara total biaya pemasaran terhadap total nilai produk (harga beli konsumen). Untuk menghitung efisiensi pemasaran dapat menggunakan rumus sebagai berikut [7]:

$$
E_{P}=\frac{T B P}{T N P} x 100 \%
$$

Dimana :

$\mathrm{Ep} \quad=$ Efisiensi pemasaran $(\%)$

$\mathrm{TBP}=$ Total biaya pemasaran $(\mathrm{Rp} / \mathrm{kg})$

$\mathrm{TNP}=$ Total nilai produk yaitu harga beli pada konsumen $(\mathrm{Rp} / \mathrm{kg})$

Margin pemasaran secara matematis dapat ditulis sebagai berikut [8].

$$
\mathrm{Mi}=\mathrm{Psi}-\mathrm{Pbi}
$$

Dimana :

$\mathrm{Mi}=$ Marjin pemasaran tingkat $\mathrm{ke}-\mathrm{i}(\mathrm{Rp} / \mathrm{kg})$

Psi = Harga jual pasar tingkat ke-i $(\mathrm{Rp} / \mathrm{kg})$

$\mathrm{Pbi}=$ Harga beli pasar tingkat $\mathrm{ke}-\mathrm{I}(\mathrm{Rp} / \mathrm{kg})$ 
$\mathrm{i} \quad=1,2,3, \ldots, \mathrm{n}$

Keuntungan pemasaran merupakan selisih antara margin pemasaran dengan biaya pemasaran yang dirumuskan sebagai berikut [9]:

Dimana :

$$
\Pi=\mathrm{Hj}-(\mathrm{Hb}+\text { Biaya })
$$

$$
\begin{array}{ll}
\Pi & =\text { Keuntungan pemasaran }(\mathrm{Rp} / \mathrm{kg}) \\
\mathrm{Hj} & =\text { Harga jual }(\mathrm{Rp} / \mathrm{kg}) \\
\mathrm{Hb} & =\text { Harga beli }(\mathrm{Rp} / \mathrm{kg}) \\
\text { Biaya } & =\text { Biaya pengeluaran }(\mathrm{Rp} / \mathrm{kg})
\end{array}
$$

Farmer's share adalah perbandingan bagian yang didapat oleh petani, dapat dirumuskan sebagai berikut:

$$
\mathrm{Fs}=\frac{\mathrm{pf}}{\mathrm{pr}} x 100 \%
$$

Dimana :

Fs = Bagian harga yang diterima petani manggis $(\%)$

$\mathrm{Pf}=$ Harga manggis di tingkat petani $(\mathrm{Rp} / \mathrm{kg})$

$\mathrm{Pr}=$ Harga manggis di tingkat konsumen akhir $(\mathrm{Rp} / \mathrm{kg})$

\section{Hasil danPembahasan}

\section{Saluran Pemasaran}

Saluran pemasaran merupakan serangkaian aktivitas yang dilakukan oleh lembaga pemasaran yang terlibat dalam proses memasarkan suatu produk dari produsen hingga ke konsumen akhir. Semakin banyak lembaga pemasaran yang terlibat dalam penyaluran suatu komoditi, maka akan semakin besar perbedaan harga komoditi tersebut di titik produsen dengan harga yang dibayar konsumen [10]. Setiap lembaga pemasaran akan melakukan fungsi-fungsi pemasaran yang dapat menciptakan kegunaan, baik guna bentuk, guna waktu dan guna tempat sehingga dapat mempermudah konsumen untuk memperoleh barang tersebut [11]. Fungsi pemasaran ini harus diakomodasikan oleh produsen, rantai saluran barang dan jasa dan lembaga - lembaga lain yang berperan dalam proses pemasaran [12]. Jika lembaga yang melakukan fungsi pemasaran mengeluarkan sedikit biaya maka pemasaran tersebut dikatakan efisien [13].

Berdasarkan data di lapangan, diketahui bahwa saluran pemasaran manggis yang ada di Desa Pulau Rambai terdapat dua bentuk saluran pemasaran yaitu :

Saluran I

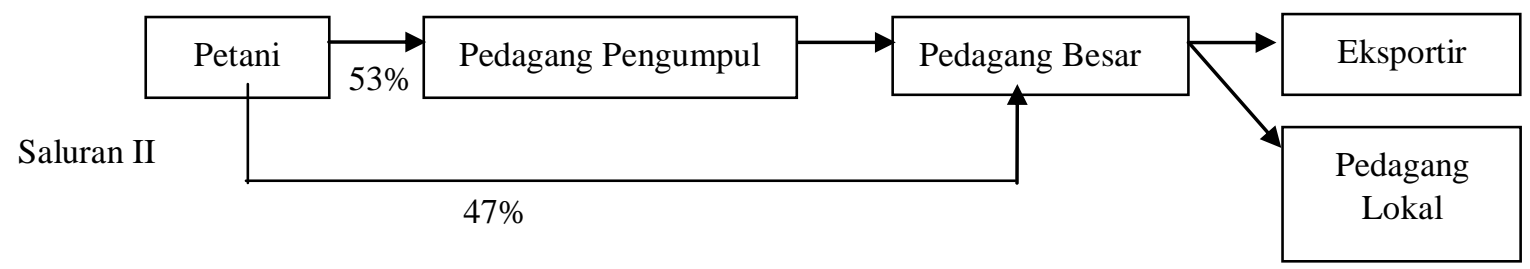

Gambar 1. Saluran pemasaran manggis di Desa Pulau Rambai

Dimana :

Eksportir : manggis kualitas super (SP)

Pedagang lokal : manggis kualitas barang sisa sortir (BS)

Pada saluran pemasaran I, dari 30 petani responden sebanyak 16 orang (53\%) menjual manggis mereka kepada pedagang pengumpul. Petani menjual manggis kepada pedagang pengumpul dengan mendatangi langsung rumah pedagang pengumpul. Dari hasil penelitian yang dilakukan di Desa Pulau Rambai terdiri dari dua dusun yaitu Pulau Rambai dan Kampung Sawah. Pedagang pengumpul dan pedagang besar adalah penduduk wilayah setempat. Pedagang besar mempunyai gudang 
manggis yang berada di Dusun Kampung Sawah, sedangkan pedagang pengumpul berada di Dusun Pulau Rambai. Keputusan petani responden untuk menjual hasil produksi manggis kepada pedagang pengumpul disebabkan oleh faktor berikut, yaitu kemudahan dalam melakukan transaksi karena apabila petani ingin menjual manggis kepada pedagang besar maka petani harus menyebrangi sungai dan petani lebih suka menjual manggis ke pedagang langganan yang dekat dengan rumah mereka. Kemudian pedagang pengumpul yang berada di Dusun Pulau Rambai yang menyebrangi sungai untuk menjual manggis ke pedagang besar yang berada di Dusun Kampung Sawah. Selanjutnya pedagang pengumpul menjual manggis ke pedagang besar. Di tingkat pedagang besar, manggis yang telah ditimbang kemudian disortir. Kegiatan penyortiran dan grading dilakukan oleh pedagang besar. Penyortiran dilakukan berdasarkan penampilan luar buah. Buah yang layak ekspor merupakan buah dengan kulitas super (SP), sedangkan buah yang tidak layak ekspor atau barang sisa sortir masuk kedalam kualitas lokal (BS). Buah dengan kualitas super (SP) dijual pedagang besar ke eksportir, sedangkan manggis yang tidak memenuhi kualitas ekspor dikategorikan sebagai kualitas lokal (BS) yang dijual kepada pedagang lokal yang datang ke gudang.

Pada saluran pemasaran II, sebanyak 14 orang (47\%) petani responden langsung menjual manggis kepada pedagang besar. Petani responden yang menjual manggis kepada pedagang besar merupakan petani Dusun Kampung Sawah. Kemudian dilakukan kegiatan penyortiran dan grading. Buah dengan kualitas super (SP) dijual kepada eksportir dan manggis yang tidak memenuhi kualitas ekspor atau barang sisa sortir (BS) dijual kepada pedagang lokal yang datang ke gudang.

\section{Fungsi-fungsi Pemasaran manggis}

Salah satu pendekatan yang digunakan untuk menganalisis pemasaran adalah pendekatan fungsi pemasaran. Pendekatan fungsi pemasaran merupakan pendekatan studi pemasaran dari aktivitasaktivitas bisnis yang terjadi pada sistem pemasaran yang akan meningkatkan dan atau menciptakan nilai guna untuk memenuhi kebutuhan (kepuasan) konsumen [14]. Kegunaan pendekatan fungsi dalam analisis pemasaran adalah untuk melihat bagaimana variasi aktivitas atau kegiatan yang dilakukan oleh lembaga yang terlibat di setiap tingkat dan semua saluran yang ada, serta kaitannya dengan biaya pemasaran yang harus dikeluarkan sehubungan kegiatan yang dilakukan lembaga tersebut pada tiap tingkat di semua saluran pemasaran yang ada. Analisis fungsi pemasaran dilakukan terhadap masingmasing lembaga pemasaran yang terlibat pada setiap saluran pemasaran manggis. Pelaksanaan fungsi pemasaran dari setiap lembaga pemasaran manggis di Desa Pulau Rambai dapat dilihat pada Tabel 1.

Tabel 1. Fungsi-fungsi Pemasaran yang Dilakukan oleh Lembaga Pemasaran Manggis

di Desa Pulau Rambai beserta Kegiatan Pemasaran

\begin{tabular}{|c|c|c|c|}
\hline No & Lembaga Pemasaran & Fungsi Pemasaran & Kegiatan Pemasaran \\
\hline \multirow[t]{3}{*}{1} & Petani & Fungsi Pertukaran & Penjualan \\
\hline & & Fungsi Fisik & Pengangkutan \\
\hline & & Fungsi Fasilitas & Penanggungan resiko dan informasi pasar \\
\hline \multirow[t]{3}{*}{2} & Pedagang Pengumpul & Fungsi Pertukaran & Penjualan dan pembelian \\
\hline & & Fungsi Fisik & Pengankutan \\
\hline & & Fungsi Fasilitas & $\begin{array}{l}\text { Sortasi, penanggungan resiko, pembiayaan dan } \\
\text { informasi pasar }\end{array}$ \\
\hline \multirow[t]{3}{*}{3} & Pedagang Besar & Fungsi Pertukaran & Penjualan dan pembelian \\
\hline & & Fungsi Fisik & Penyimpanan, pengangkutan dan pengemasan \\
\hline & & Fungsi Fasilitas & $\begin{array}{l}\text { Sortasi dan grading, penanggungan resiko, pembiayaan } \\
\text { dan informasi pasar }\end{array}$ \\
\hline
\end{tabular}

1. Fungsi Pemasaran Petani

Fungsi-fungsi pemasaran yang dilakukan oleh petani responden manggis yaitu fungsi pertukaran, fungsi fisik, dan fungsi fasilitas. Fungsi pertukaran yang dilakukan petani manggis adalah kegiatan penjualan. Pada fungsi pertukaran,dari 30 petani responden sebanyak 16 orang (53\%) menjual manggis ke pedagang pengumpul dan sisanya 14 orang petani responden (47\%) langsung menjual manggis ke pedagang besar. Dari hasil penelitian yang dilakukan di Desa Pulau Rambai terdiri dari dua dusun yaitu Pulau Rambai dan Kampung Sawah.Tempat tinggal pedagang pengumpul berada di Dusun Pulau Rambai sedangkan gudang manggis pedagang besar berada di Dusun Kampung Sawah. Petani yang menjual manggis ke pedagang pengumpul adalah petani yang bertempat tinggal di Dusun Pulau Rambai dan petani yang menjual manggis ke pedagang 
besar adalah petani yang tinggal di Dusun Kampung Sawah. Petani menjual manggis kepada pedagang pengumpul dengan mendatangi langsung rumah pedagang pengumpul. Keputusan petani untuk menjual hasil produksi manggis kepada pedagang pengumpul disebabkan oleh faktor berikut, yaitu kemudahan dalam melakukan transaksi karena petani harus menyebrangi sungai apabila menjual ke pedagang besar. Manggis yang dibawa oleh petani langsung ditimbang dan dibayar pedagang pengumpul sesuai dengan bobot dan kualitas buah secara umum. Pembayaran umumnya dilakukan secara tunai setelah penimbangan.

Fungsi fisik yang dilakukan berupa kegiatan pengangkutan yaitu petani melakukan pengangkutan manggis dari kebun manggis petani ke rumah pedagang pengumpul dan gudang manggis pedagang besar. Petani mengangkut manggis menggunakan kantong plastik.Transaksi petani manggis dengan pedagang berlangsung setiap sekali dua hari. Fungsi fasilitas yang dilakukan oleh petani manggis berupa aktivitas informasi pasar dan penanggung risiko. Aktifitas informasi pasar dimana petani manggis mendapatkan informasi mengenai harga dari sesama petani manggis maupun pedagang pengumpul melalui telfon. Kegiatan penanggung risiko yaitu jika ada manggis yang mengalami kecacatan atau kebusukan maka manggis tersebut dikategorikan grade BS sehingga menyebabkan keuntungan petani menurun karena ditanggung oleh petani manggis sendiri.

\section{Fungsi Pemasaran Pedagang Pengumpul}

Pedagang pengumpul di Desa Pulau Rambai berjumlah satu orang. Pedagang pengumpul melakukan semua fungsi pemasaran seperti fungsi pertukaran, fungsi fisik, dan fungsi fasilitas. Fungsi pertukaran yang dilakukan oleh pedagang pengumpul berupa kegiatan pembelian dan penjualan. Pedagang pengumpul membeli manggis dari petani yang berada di Dusun Pulau Rambai. Pedagang pengumpul hanya menunggu petani yang datang menjual manggis dan melakukan transaksi di rumah pedagang pengumpul. Harga pembelian ditentukan oleh pedagang pengumpul berdasarkan informasi harga dari pedagang besar. Pembayaran dari pedagang pengumpul kepada petani dilakukan secara tunai. Selanjutnya pedagang pengumpul melakukan penjualan manggis kepada pedagang besar yang berada di Dusun Kampung Sawah.

Fungsi fisik yang dilakukan oleh pedagang pengumpul berupa fungsi pengangkutan, dimana pedagang pengumpul menjual manggis yang telah dikumpulkan dari petani ke pedagang besar yang berada di Dusun Kampung Sawah dengan menggunakan motor yang dilengkapi dengan keranjang bambu. Kegiatan pengangkutan dilakukan setiap hari sampai musim panen manggis berakhir. Fungsi fasilitas yang dilakukan pedagang pengumpul meliputi fungsi informasi pasar, penanggung risiko, sortasi dan pembiayaan. Fungsi informasi pasar dibutuhkan oleh pedagang pengumpul untuk mengetahui perkembangan harga jual manggis yang diperoleh dari pedagang besar. Penanggungan risiko dilihat dari seberapa banyak persentase antara buah manggis grade super (SP) dan bekas sortir (BS). Pedagang pengumpul membeli manggis grade SP sebanyak $14.723,00 \mathrm{~kg}(70,31 \%)$ dan grade BS sebanyak $6.216,20 \mathrm{~kg}(29,69 \%)$. Harga beli manggis oleh pedagang pengumpul sebesar Rp $11.500,00$ untuk grade SP dan Rp 5.500,00 untuk grade BS. Fungsi sortasi dilakukan oleh pedagang pengumpul berdasarkan penampilan luar buah. Sortasi ini dilakukan dengan memisahkan buah manggis grade super (SP) dan bekas sortir (BS). Fungsi pembiayaan yang dilakukan oleh pedagang pengumpul yaitu penyediaan modal untuk melakukan pembelian manggis dari petani serta biaya selama perjalanan seperti upah pengangkutan.

\section{Fungsi Pemasaran Pedagang Besar}

Fungsi pemasaran yang dilakukan oleh pedagang besar adalah fungsi pertukaran, fungsi fisik, dan fungsi fasilitas. Fungsi pertukaran yang dilakukan oleh pedagang besar berupa fungsi penjualan dan fungsi pembelian. Pedagang besar membeli manggis dari pedagang pengumpul dan dari petani. Pedagang besar hanya menunggu petani dan pedagang pengumpul yang datang menjual manggis ke gudang. Sistem pembayaran yang dilakukan adalah secara tunai. Fungsi penjualan yang dilakukan oleh pedagang besar adalah melakukan penjualan kepada eksportir untuk manggis kualitas super (SP) dan pedagang lokal untuk manggis bekas sortir (BS). Adapun sistem pembayaran dilakukan oleh eksportir yaitu dengan cara transfer melalui nomor rekening pedagang besar dan pembayaran oleh pedagang lokal dilakukan secara tunai.

Fungsi fisik yang dilakukan oleh pedagang besar adalah fungsi pengangkutan, pengemasan dan penyimpanan sementara. Fungsi pengangkutan yang dilakukan oleh pedagang besar yang berada di 
Desa Pulau Rambai adalah melakukan pengiriman manggis ke eksportir yang berada di Dumai dengan menggunakan mobil. Pengiriman dilakukan setiap hari sampai musim panen manggis berakhir. Fungsi pengemasan yang dilakukan pedagang besar yaitu manggis yang telah di sortasi dan grading selanjutnya dikemas dalam keranjang sepuluh kilogram yang diberi alas kertas dan busa tipis. Penyimpanan sementara dilakukan sampai ada pengiriman selanjutnya.

Fungsi fasilitas yang dilakukan oleh pedagang besar berupa sortasi dan grading, informasi pasar, penanggung risiko, dan pembiayaan. Manggis yang telah ditimbang kemudian dilakukan kegiatan penyortiran dan grading. Buah yang layak ekspor merupakan buah dengan kulitas super (SP), sedangkan buah yang tidak layak ekspor atau bekas sortir masuk kedalam kualitas lokal (BS). Berdasarkan hasil wawancara dengan petani responden dan pedagang kriteria buah dengan kualitas super adalah buah yang memiliki sepal lengkap dan segar, penampakan buah segar, bentuk warna dan rasa buah sesuai varietas, keadaan baik (tidak busuk/rusak), layak konsumsi, bersih bebas dari benda asing, bebas dari segala bentuk kontaminasi pestisida dan benda asing lainnya, bebas dari penyakit getah kuning, bebas dari kerusakan yang disebabkan oleh hama dan penyakit. Buah dengan kualitas super yang diekspor kemudian dilakukan kegiatan grading yaitu kegiatan mengelompokkan produk menurut ukuran-ukuran tertentu sehingga memudahkan pemasaran produk tersebut. Hal ini mempunyai manfaat untuk memudahkan menilai produk dengan harga baik oleh penjual dan pembeli, memudahkan proses jual beli, memudahkan pengumpulan produk dan mempertinggi permintaan konsumen sesuai daya beli dan selera. Grading manggis dilakukan berdasarkan ukuran dan dikelompokkan dalam kelas/grade AAAA, AAA, dan AA. Ukuran buah manggis untuk grade AAAA berjumlah 13-18 buah per kilogram, grade AAA berjumlah 7-12 buah per kilogram dan untuk grade AA berjumlah 4-6 buah per kilogram. Walaupun buah dengan kualitas super yang diekspor terdiri dari tiga grade tetapi harga jualnya sama. Manggis yang tidak memenuhi kualitas ekspor dikategorikan sebagai kualitas lokal (BS) yang dijual kepada pedagang lokal yang datang ke gudang. Pedagang lokal yang datang membeli tidak tetap dan terus berganti. Fungsi penanggung risiko yang ditanggung pedagang besar berupa penyusutan atau buah yang busuk, terjadinya fluktuasi harga manggis, kapasitas permintaan barang dari pihak eksportir dan musim panen di negara tujuan ekspor. Fungsi pembiayaan yang dilakukan pedagang besar yaitu penyediaan modal untuk membayar upah terhadap tenaga kerja serta transportasi. Fungsi informasi harga diperoleh dari eksportir sebagai konsumen akhir yang dibutuhkan untuk mengetahui perkembangan harga jual dan harga beli manggis yang terkait dengan harga yang harus dibayarkan kepada petani.

\section{Biaya dan Efisiensi Pemasaran}

Analisis biaya pemasaran merupakan biaya yang dikeluaran untuk kegiatan atau aktifitas usaha pemasaran komoditi manggis. Efisiensi pemasaran buah manggis dapat dilihat melalui margin pemasaran. Margin pemasaran merupakan perbedaan harga ditingkat petani dengan harga ditingkat konsumen akhir. Margin pemasaran yang besar menunjukkan besarnya harga dari penambahan kegunaan dan fungsi-fungsi pemasaran yang dilaksanakan serta keuntungan di setiap lembaga pemasaran. Analisis marjin pemasaran dilakukan untuk melihat perbedaan harga di tingkat petani dengan harga ditingkat konsumen. Nilai marjin pemasaran akan menentukan besarnya bagian harga yang diterima petani di setiap saluran pemasaran dari harga yang didapat pada tingkat konsumen akhir. Pada setiap saluran pemasaran terdapat perbedaan pada nilai total margin pemasaran. Sebaran marjin pemasaran pada sistem pemasaran buah manggis dapat dilihat pada Tabel 2. Hal tersebut mengindikasikan terjadinya perbedaan besaran biaya yang disebabkan oleh biaya yang diakibatkan terlaksananya fungsi-fungsi pemasaran yang dilakukan oleh masing-masing lembaga pemasaran.

Konsumen akhir dalam penelitian ini dibatasi sampai eksportir untuk manggis dengan kualitas super dan pedagang lokal untuk manggis kualitas barang bekas sortir. Hal ini disebabkan adanya keterbatasan waktu dan biaya dalam penelitian apabila saluran pemasaran ditelusuri lebih lanjut maka eksportir akan menjual manggis ke negara-negara tujuan ekspor dan pedagang lokal yang datang membeli tidak tetap dan terus berganti.

Tabel 2 menunjukkan bahwa margin pemasaran pada saluran pemasaran I sebesar Rp $1.000,00 / \mathrm{kg}$ di tingkat pedagang pengumpul dan sebesar Rp 11.500,00/kg di tingkat pedaganag besar dengan total margin sebesar Rp 12.500,00/kg. Margin ini diperoleh dari rata-rata harga jual petani yaitu dari harga beli pedagang pengumpul dengan harga $\mathrm{Rp} 11.500,00 / \mathrm{kg}$, kemudian pedagang pengumpul menjual kepada pedagang besar dengan harga $\mathrm{Rp} 12.500,00 / \mathrm{kg}$ dan pedagang besar menjual kepada eksportir sebagai konsumen akhir dengan harga Rp 24.000,00/kg . Pada saluran I 
didapat total biaya pemasaran di tingkat pedagang pengumpul sebesar Rp 149,52/kg. Sedangkan di tingkat pedagang besar didapat total biaya pemasaran sebesar Rp 5.545,73/kg. Total keuntungan pemasaran yang didapat sebesar Rp 6.804,75/kg, dimana keuntungan pedagang pengumpul sebesar Rp $850,48 / \mathrm{kg}$ dan keuntungan pedagang besar sebesar Rp 5.954,27,95/kg. Nilai efisiensi pemasaran pada saluran I grade SP adalah $23,73 \%$, yang artinya persentase perbedaan biaya pemasaran manggis dengan total nilai produk adalah sebesar $23,73 \%$.

Tabel 2. Sebaran margin pemasaran manggis setiap saluran di Desa Pulau Rambai

\begin{tabular}{|c|c|c|c|c|}
\hline \multirow{3}{*}{ Lembaga Pemasaran } & \multicolumn{4}{|c|}{ Saluran Pemasran $(\mathrm{Rp} / \mathrm{Kg})$} \\
\hline & \multicolumn{2}{|r|}{ 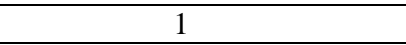 } & \multicolumn{2}{|c|}{2} \\
\hline & Grade SP & Grade BS & Grade SP & Grade BS \\
\hline \multicolumn{5}{|l|}{ Petani } \\
\hline Harga Jual & $11.500,00$ & $5.500,00$ & $12.000,00$ & $5.750,00$ \\
\hline \multicolumn{5}{|l|}{ Pedagang Pengumpul } \\
\hline Harga Beli & $11.500,00$ & $5.500,00$ & & \\
\hline Harga Jual & $12.500,00$ & $6.000,00$ & & \\
\hline Biaya Pemasaran & 149,52 & 354,13 & & \\
\hline Margin & $1.000,00$ & 500,00 & & \\
\hline Keuntungan & 850,48 & 145,87 & & \\
\hline \multicolumn{5}{|l|}{ Pedagang Besar } \\
\hline Harga Beli & $12.500,00$ & $6.000,00$ & $12.000,00$ & $5.750,00$ \\
\hline Harga Jual & $24.000,00$ & $8.000,00$ & $24.000,00$ & $7.900,00$ \\
\hline Biaya Pemasaran & $5.545,37$ & $1.805,66$ & $5.063,44$ & $1.354,61$ \\
\hline Margin & $11.500,00$ & $2.000,00$ & $12.000,00$ & $2.150,00$ \\
\hline Keuntungan & $5.954,27$ & 194,34 & $6.936,56$ & 795,39 \\
\hline \multicolumn{5}{|c|}{ Konsmen Akhir(Eksportir/Pedagang Lokal) } \\
\hline Harga Beli & $24.000,00$ & $8.000,00$ & $24.000,00$ & $7.900,00$ \\
\hline Total Margin Pemasaran & 12.500 & $2.500,00$ & $12.000,00$ & $2.150,00$ \\
\hline Total Biaya Pemasaran & $5.695,25$ & $2.159,79$ & $5.063,44$ & $1.354,61$ \\
\hline Total Keuntungan Pemasaran & $6.804,75$ & 340,21 & $6.936,56$ & 795,39 \\
\hline Farmer Share's & 47,92 & 68,75 & 50,00 & 72,78 \\
\hline Efisiensi Pemasaran & 23,73 & 27,00 & 21,10 & 17,15 \\
\hline
\end{tabular}

Keterangan : Grade SP : kualitas super $\rightarrow$ eksportir

Grade BS : kualitas barang bekas sortir $\rightarrow$ pedagang lokal

Nilai margin pemasaran pada saluran pemasaran I grade BS sebesar Rp 500,00/kg di tingkat pedagang pengumpul dan sebesar Rp $2.000,00 / \mathrm{kg}$ di tingkat pedagang besar dengan total margin sebesar Rp 2.500,00/kg. Margin ini diperoleh dari rata-rata harga jual petani yaitu dari harga beli pedagang pengumpul dengan harga $\mathrm{Rp} 5.500,00 / \mathrm{kg}$, kemudian pedagang pengumpul menjual kepada pedagang besar dengan harga $\mathrm{Rp} 6.000,00 / \mathrm{kg}$ dan pedagang besar menjual kepada pedagang lokal sebagai konsumen akhir dengan harga Rp 8.000,00/kg.Total biaya pemasaran untuk grade BS saluran

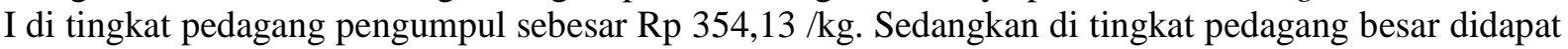
total biaya pemasaran sebesar Rp 1.805,66/kg. Total keuntungan pemasaran yang didapat sebesar Rp $340,21 / \mathrm{kg}$, dimana keuntungan pedagang pengumpul sebesar Rp 145,87/kg dan keuntungan pedagang besar sebesar Rp 194,34/kg. Nilai efisiensi pemasaran pada saluran I grade BS adalah 27,00\%, artinya persentase perbedaan biaya pemasaran manggis dengan total nilai produk adalah sebesar $27,00 \%$.

Total margin pemasaran pada saluran pemasaran II grade SP sebesar Rp 12.000,00/kg. Margin ini diperoleh dari rata-rata harga jual petani yaitu dari harga beli pedagang besar dengan harga $\mathrm{Rp}$ $12.000,00 / \mathrm{kg}$, kemudian pedagang besar menjual kepada eksportir dengan harga Rp 24.000,00/kg. Total biaya pemasaran grade SP sebesar Rp 5063,44/kg dan total keuntungan pemasaran sebesar Rp $6936,56 / \mathrm{kg}$. Nilai efisiensi pemasaran pada saluran II grade SP adalah $21,10 \%$, yang artinya persentase perbedaan biaya pemasaran manggis dengan total nilai produk adalah sebesar $21,10 \%$.

Total margin pemasaran pada saluran pemasaran II grade BS sebesar Rp 2.150,00/kg. Margin ini diperoleh dari rata-rata harga jual petani yaitu dari harga beli pedagang besar dengan harga $\mathrm{Rp}$ $5.750,00 / \mathrm{kg}$, kemudian pedagang besar menjual kepada pedagang lokal sebagai konsumen akhir yang datang membeli ke gudang dengan harga Rp 7.900,00/kg. Total biaya pemasaran grade BS sebesar Rp $1354,61 / \mathrm{kg}$ dan total keuntungan pemasaran sebesar Rp 795,39/kg. Nilai efisiensi pemasaran pada saluran II grade BS adalah $17,15 \%$, yang artinya persentase perbedaan biaya pemasaran manggis dengan total nilai produk adalah sebesar $17,15 \%$. 
Saluran pemasaran yang efisien di Desa Pulau Rambai berdasarkan analisis margin pemasaran adalah saluran yang memiliki nilai margin terkecil. Berdasarkan kedua saluran yang ada, saluran yang memiliki nilai margin terkecil adalah saluran II. Nilai efisiensi pada saluran pemasaran II lebih kecil dibanding nilai efisiensi pada saluran pemasaran I yaitu sebesar $21,10 \%$ untuk grade SP dan $17,15 \%$ untuk grade BS. Hal ini menunjukkan bahwa saluran pemasaran II lebih efisien untuk dijalankan. Artinya semakin panjang saluran pemasaran yang digunakan maka akan semakin kecil efisiensi pemasaran yang dilakukan. Menurut Soekartawi [15] nilai efisiensi pemasaran ini dilihat dengan membandingkan nilai efisiensi pemasaran pada tiap-tiap saluran pemasaran. Apabila nilai efisiensi pemasaran suatu saluran pemasaran lebih kecil dari nilai efisiensi saluran pemasaran lainnya, maka saluran pemasaran tersebut dikatakan memiliki efisiensi pemasaran yang lebih tinggi daripada saluran pemasaran lainnya. Tingkat efisiensi berdasarkan farmer's share adalah saluran yang memiliki nilai farmer's share terbesar. Nilai farmer's share terbesar terdapat pada saluran II dengan nilai farmer's share sebesar 50,00\%, ini berarti petani memperoleh bagian sebanyak 50,00\% untuk grade SP dam $72,78 \%$ untuk grade BS dari harga beli yang diterima konsumen akhir. Dapat disimpulkan bahwa saluran yang paling efisien dilihat dari perhitungan biaya pemasaran, margin pemasaran, farmer share's dan efisiensi pemasaran adalah di saluran pemasaran dua.

\section{Kesimpulan}

Pada sistem pemasaran manggis, terdapat dua lembaga pemasaran selain petani di Desa Pulau Rambai yaitu pedagang pengumpul dan pedagang besar. Saluran pemasaran manggis terdiri dari dua saluran pemasaran. Fungsi-fungsi pemasaran dilakukan oleh setiap lembaga pemasaran yaitu fungsi pertukaran, fungsi fisik dan fungsi fasilitas. Fungsi pertukaran yang dilakukan berupa fungsi penjualan dan pembelian. Fungsi fisik yang dilakukan berupa fungsi pengemasan, pengangkutan dan penyimpanan. Fungsi fasilitas yang dilaksanakan berupa fungsi sortasi dan grading, pembiayaan, penanggungan risiko dan informasi pasar. Analisis efisiensi saluran pemasaran berdasarkan perhitungan biaya pemasaran dan efisiensi pemasaran maka saluran pemasaran yang paling efisien adalah saluran dua.

\section{Daftar Pustaka}

[1] Saptana, Daryanto A, Daryanto HK, dan Kuntjoro. 2010. Analisis Efisiensi Teknis Usahatani Cabai Merah Besar dan Perilaku Petani dalam Menghadapi Risiko. Jurnal Agro Ekonomi 28 (2): 153-188. (Jurnal)

[2] Sumantra, I. K., Wiswasta, I. A., Sujana, I. P. dan Widnyana, I. K. 2010. Peningkatan produksi dan pendapatan petani manggis melalui penerapan teknologi pembuahan manggis di luar musim di Selemadeg, Tabanan. J. Majalah Aplikasi Ipteks Nganyah. 1(1) : 71-80. (Jurnal)

[3] Direktorat Budidaya Tanaman Buah. 2009. Standard Operating Procedure Manggis Kabupaten Sukabumi. Jakarta (ID): Direktorat Budidaya Tanaman Buah. Direktorat Jendral Hortikultura.

[4] Badan Pusat Statistik Jakarta. 2016. Jakarta dalam angka 2016. Jakarta.

[5] Purnamasari, I. A. 2010. Analisis Pemasaran Jeruk di Kabupaten Bangli. Skripsi (Tidak dipublikasikan). Universitas Sebelas Maret. Surakarta.

[6] Anita, Muani A, Suyatno A. 2012. Analisis Efisiensi Pemasaran Jeruk Siam di Kecamatan Tebas Kabupaten Sambas. Jurnal Sains Mahasiswa Pertanian .1 (1): 22-31. (Jurnal)

[7] Soekartawi. 2002. Prinsip Dasar Ekonomi Pertanian. PT. Raja Grafindo Persada. Jakarta.

[8] Sudiyono, A. 2001. Pemasaran Pertanian. Universitas Muhamadyah Malang. Malang

[9] Soekartawi. 2002. Prinsip Dasar Ekonomi Pertanian. PT. Raja Grafindo Persada. Jakarta.

[10] Supena, M. H. 2015. Analisis margin tata niaga ikan lemadang dan ikan terisi di TPI Mina Fajar Sidik, Kec. Blanakan, Kab. Subang, Jawa Barat. J. Penyuluhan Perikanan dan Kelautan. 9(2) : 47-60. (Jurnal)

[11] Herliadi, W., Herdiansah, D. dan Ramdan, M. 2015. Analisis pemasaran kapulaga (Studi kasus pada Kelompok Tani Cimanggu I di Desa Cimanggu Kecamatan Langkaplancar Kabupaten Pangandaran). J. Ilmiah Mahasiswa Agroinfo Galuh. 1(3) : 201-202. (Jurnal)

[12] Hasyim, A. I. 2012. Tataniaga Pertanian. Buku. Universitas Lampung. Bandar Lampung. 253 hlm 
[13] Firdaus, M. E., Sujaya, D. H. dan Hardiyanto, T. 2017. Analisis saluran pemasaran gula aren (Suatu kasus di Desa Cikuya Kecamatan Culamega Kabupaten Tasikmalaya). J. Ilmiah Mahasiswa Agroinfo Galuh. 4(3) : 418- 425. (Jurnal)

[14] Asmarantaka RW. 2012. Pemasaran Agribisnis (Agrimarketing). Skripsi. Departemen Agribisnis FEM-IPB. Bogor. Departemen Pertanian. Jakarta.

[15] Soekartawi. 2003. Teori Ekonomi Produksi. PT. Raja Grafindo Persada. Jakarta. 